\title{
Acetate absorption and metabolism in the rabbit hindgut
}

\author{
J F MARTY, M Y VERNAY, AND G M ABRAVANEL \\ From the Institute of Physiology, Toulouse, France
}

SUMmARY Acetate disappearance from the loops of the hindgut in the rabbit was evaluated by measuring variations in the concentration of acetate in caecocolonic loops and differences in the arterial and venous plasma. In vivo metabolism in gut and liver tissues was studied after introduction of $\left(1-{ }^{14} \mathrm{C}\right)$ acetate into caecocolonic loops. The rate of disappearance from the loops was quantitatively significant and showed little variation irrespective of the location in the hindgut. Hindgut tissue metabolised acetate and the intensity of the metabolism varied with the segment studied. The distal position of the gut showed by far the highest acetate uptake. Radioactivity was found in a certain number of free amino acids, organic acids, and sugars. Acetate was mainly converted into aspartate and glutamate. These can be considered as 'stock forms' which can be diverted either towards oxidative metabolism or towards protein synthesis.

A large proportion of the energy requirement of the rabbit is derived from the metabolism of volatile fatty acids (VFA) formed by microbial fermentation of the fodder in the large intestine. ${ }^{12}$ Substantial amounts of acetate, propionate, and butyrate appear in caecocolonic contents and are subjected to metabolic activity in the hindgut epithelium during their absorption. ${ }^{3-7}$ In an earlier paper $^{8}$ we observed that large intestine tissues metabolise butyrate, the intensity of this metabolism varying with the location in the gut and with the nature of the pellets contained in the colon. We showed that butyrate is the best respiratory fuel for the colonic wall, its oxidation into carbon dioxide in the TCA cycle yielding energy for metabolic activity and for the absorption of electrolytes ${ }^{9-12}$ and of numerous bacterial constituents liberated by the intervention of a lytic protein. This protein isolated and characterised by Bonnafous and Raynaud ${ }^{13-15}$ is responsible for the steady fall in the bacterial population of the proximal and distal colon of the rabbit. Acetate is the major fatty acid present in the hindgut contents $(73 \%),{ }^{6}$ however, its turnover rate through the caecal pool is rapid and 10 -fold higher than that calculated for the rumen of the cow. ${ }^{2}$ Much less information is available about its

Address for correspondence: Dr M Y Vernay. Laboratoire de la digestion et de la Nutrition. Institut de Physiologie, 2 rue F Magendie. 31400 ToulouseFrance.

Received for publication 19 July 1984 metabolism by caecal and colonic mucosa. McMillan et al ${ }^{16}$ reported that acetate absorption in the caecum occurs with little or no metabolic change; Henning and Hird $^{3}{ }^{4}$ showed that acetate is only slightly oxidised by hindgut mucosa.

The aim of the present investigation is to determine the extent to which acetate is metabolised during its absorption from the hindgut.

\section{Methods}

ANIMALS

Twelve male rabbits (Oryctolagus cuniculus) with an average weight of $2.5 \mathrm{~kg}$ were provided with oats, lucerne, and ad libitum water. Animals were not selected according to the nature of the pellets contained in their colon, as the study of the variations linked to the excretory rhythm were not the purpose of this work.

EXPERIMENTAL PROCEDURE

Anaesthesia of the rabbits was achieved by administering pentobarbital solution $(20 \mathrm{mg} / \mathrm{kg})$, through the marginal vein of the ear. After laparotomy the intestine was removed and three loops of approximately equivalent parameters, as indicated in Table 1, were made from the caecum (median zone) and the proximal and distal colon. The sites of the loops were chosen for suitability for cannulation of the venous drainage. Polyethylene catheters (PE90) were inserted into small 
Table 1 Mean weight and serosal area of caecocolonic loops

\begin{tabular}{|c|c|c|c|}
\hline \multirow[b]{2}{*}{ Parameters } & \multicolumn{3}{|c|}{ Intestinal loops } \\
\hline & Caecum & $\begin{array}{l}\text { Proximal } \\
\text { colon }\end{array}$ & $\begin{array}{l}\text { Distal } \\
\text { colon }\end{array}$ \\
\hline Dry tissue & $1 \cdot 5 \pm 0 \cdot(08$ & $1 \cdot 1 \pm 0 \cdot 05$ & $0.9 \pm 0.06$ \\
\hline Wet tissue & $6 \cdot 3 \pm 1 \cdot 89$ & $6 \cdot 5 \pm 1 \cdot 24$ & $5 \cdot 1 \pm 1 \cdot 32$ \\
\hline Serosal area & $27 \cdot 0 \pm 1 \cdot 36$ & $26 \cdot 0 \pm 1 \cdot 37$ & $23 \cdot 0 \pm 1 \cdot 08$ \\
\hline
\end{tabular}

The weight of tissue is expressed in $\mathrm{g}$ on a dry or wet basis. the serosal area in $\mathrm{cm}^{2}$. Each value represents the mean $\pm S E$ of 12 samples. There was no statistically significant difference between the weights or the serosal areas of the different loops.

caecal and colonic veins draining each loop and care was taken to ensure that blood circulation was not damaged. A carotid artery was exposed and cannulated (PE190). The content of the loops was carefully washed out with sodium chloride $(9 \mathrm{~g} / \mathrm{l})$ at $38^{\circ} \mathrm{C}$. Each animal so prepared was put into a thermoregulated chamber. The three loops were filled with $5 \mathrm{ml}$ of experimental solution ${ }^{17}$ containing $2 \mathrm{~g} / \mathrm{l}$ polyethylene glycol (PEG). For the six metabolism studies, $30 \mu \mathrm{Ci}$ of $\left(1-{ }^{14} \mathrm{C}\right)$ acetate was added to the test solution. Blood samples (1 $\mathrm{ml}$ ) were simultaneously collected through the catheters before and every five minutes for 20 minutes in a heparinized beaker. After each operation the volume of blood withdrawn was replaced with physiological saline and the catheter was filled with a solution of heparin $(40 \mathrm{IU} / \mathrm{ml}$ physiological saline). At the end of the incubation $(20 \mathrm{~min})$ the loops were emptied and the contents were immediately placed in ice. The intestinal loops together with a portion of each lobe of the liver were resected, blotted, and weighed. The serosal area of the loops was evaluated by planimetry and dry weight determined after drying to constant weight.

METABOLITE DETERMINATION

For the studies on ${ }^{14} \mathrm{C}$ incorporation we adapted the method of Schurmann ${ }^{18}$ and Lavergne et al ${ }^{19}$ which separates free amino acids, organic acids, and sugars on the same autoradiographs. The tissues were homogenised in ice cold water using an Ultra-Turrax electric blender. The homogenates were extracted in boiling water and the insoluble fraction was removed by centrifugation $(30 \mathrm{~min}$ at $10000 \mathrm{~g}$ ). In order to obtain an adequate aqueous phase the lipid-soluble substances were eliminated with chloroform (three extractions $\mathrm{v} / \mathrm{v}$ ) in a separation funnel. For plasma samples protein precipitation with sulphosalicylic acid (15 g/l) preceded the chloroform extraction procedure. The aqueous phase was recovered and concentrated in a Rotavapor (Büchi). An aliquot part of this liquor was first submitted to electrophoresis $(2100 \mathrm{~V}, 40 \mathrm{~mA}, 1 \mathrm{~h})$ in an acid medium: formic acid/acetic acid/water (17:57:926, v/v) at pH 2 . After drying, double development ascendant chromatography was used in butan-2-ol/formic acid/ water $(6: 1: 2, v / v)$. The autoradiographs (Fig. 1) were obtained by leaving the electrophoresis paper in prolonged contact with photographic plates (Kodak Kodirex). The radioactive spots were eluted and ${ }^{14} \mathrm{C}$ activity was determined in a liquid scintillation counter (Packard 460). The remains of the extract was fractionated on cationic (Dowex $50 \times 4$ ) and anionic (Dowex $1 \times 4$ ) exchange resin columns in preparation for quantitative analysis. Free amino acid determination was made on a technicon autoanalysor. ${ }^{20}$ Organic acids were evaluated by potentiometry as described by Carles. ${ }^{21}$ Acetate was determined by a gas liquid chromatography (Intersmat IGC 120 DSL), after preparation using the technique described by Rémésy and Demigné. ${ }^{22}$ Polyethylene glycol concentration was determined according to the procedure described by Hyden. ${ }^{23}$

\section{STATISTICS}

The formula used in calculating net acetate transport in the intestinal loops was:

Net acetate transport $(\mu \mathrm{mol})$

$$
=\mathrm{C}_{0} \mathrm{~V}_{0}-\mathrm{CtV}_{0} \mathrm{PEG}_{0} / \mathrm{PEG}
$$

where $V_{0}$ is the volume of fluid in loops at the beginning of the experiment $(\mathrm{ml}) ; \mathrm{PEG}_{0}$ and $\mathrm{PEG}$ are the PEG concentrations at the beginning and at the end of the experiment and $\mathrm{C}_{0}$ and $\mathrm{Ct}$ are the acetate concentrations $(\mu \mathrm{mol} / \mathrm{ml})$ at the beginning and at the end of the experiment.

The formula used in calculating specific radioactivity $(S R)$ for a radioactive metabolite $A$ was:

$$
\mathrm{SR}(\mu \mathrm{Ci} / \mu \mathrm{mol})=\mathrm{Rt} \times \mathrm{Ql} / \mathrm{At}
$$

where $\mathrm{Rt}$ represents the percentage of ${ }^{14} \mathrm{C}$ incorporated into labelled metabolite $A$, it is expressed as a percentage of the total ${ }^{14} \mathrm{C}$ detected on the autoradiograph; $\mathrm{Ql}$ is the quantity of $\left(1-{ }^{14} \mathrm{C}\right)$ acetate that has disappeared from the loop $(\mu \mathrm{Ci} / 20$ $\min )$; At is the concentration of the unlabelled metabolite $\mathrm{A}$ in the tissue concerned $(\mu \mathrm{mol} / 100 \mathrm{~g}$ wet $\mathrm{wt})$ or in the plasma $(\mu \mathrm{mol} / 100 \mathrm{ml})$.

The data were expressed as means $\pm S E$; the statistical significance of the differences between means was assessed with Student's $t$ test or with the paired t-test when appropriate. 


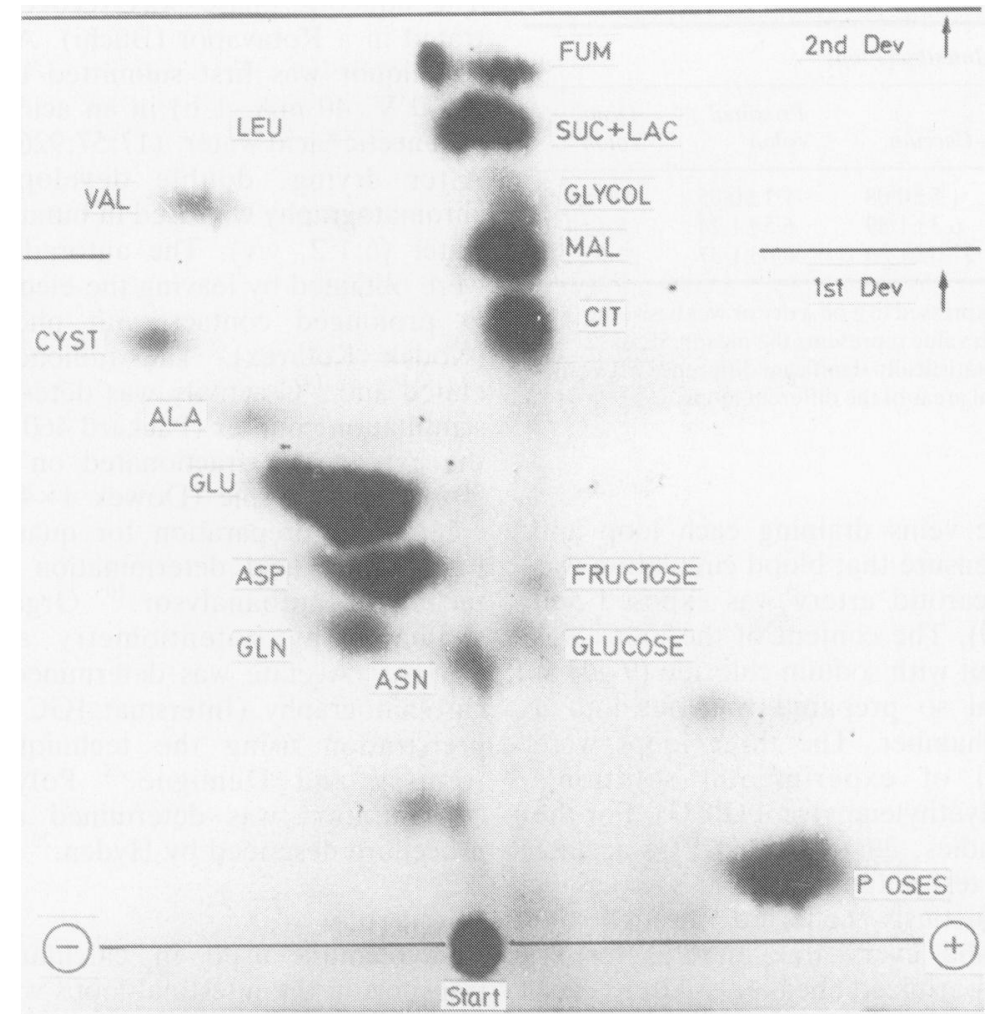

Fig. 1 Autoradiograph of metabolites incorporated into gut or liver tissues after introduction of $\left(1-{ }^{14} \mathrm{C}\right)$ acetate into caecocolonic loops. Free amino acids: alanine, aspartate, asparagine, cysteine, glutamate, glutamine, leucine and valine. Organic acids: TCA cycle acids (citrate, fumarate, malate, succinate), lactate and glycolate. Sugars: fructose, glucose and phosphorylating sugars ( $P$-oses)

\section{Results}

Disappearance of acetate in intestinal loops The concentration of acetate used in the present work was: $37.0 \pm 0.53 \mathrm{mM}$ which is regarded as physiological. ${ }^{17}$ Twenty minutes after introduction of the test solution, the rate of acetate disappearance from the caecal loops did not differ from either that of the proximal or distal colonic loops. At the end of incubation $30-35 \%$ of the acetate inserted into the loops had disappeared (Table 2; Fig. 2).

Arterial and venous plasma concentrations of acetate There was an aborally decreasing gradient of acetate in the venous hindgut plasma (Fig. 2). Differences in the concentrations of acetate in the arterial and venous plasma in the distal colon was not significant. The mean value of acetate in arterial plasma was $177 \pm 19.9 \mu \mathrm{mol} / 100 \mathrm{ml}$, which represents $88 \%$ of the total VFA.

Table 2 Mean disappearance of acetate in the caecocolonic loops

\begin{tabular}{|c|c|c|c|}
\hline \multirow[b]{2}{*}{$\begin{array}{l}\text { Disappearance } \\
\text { expressions }\end{array}$} & \multicolumn{3}{|c|}{ Intestinal loops } \\
\hline & Caecum & $\begin{array}{l}\text { Proximal } \\
\text { colon }\end{array}$ & $\begin{array}{l}\text { Distal } \\
\text { colon }\end{array}$ \\
\hline Perg dry tissuc & $57 \cdot 6 \pm 4 \cdot 84$ & $66 \cdot 1 \pm 5 \cdot 59$ & $54 \cdot 4 \pm 2.97$ \\
\hline Perg wet tissue & $14 \cdot 4 \pm 1 \cdot 21$ & $11 \cdot 6 \pm 1 \cdot 88$ & $15 \cdot 1 \pm 1 \cdot 67$ \\
\hline Per cm ${ }^{2}$ & $2 \cdot 5 \pm(0 \cdot 19$ & $3 \cdot 0 \pm 0 \cdot 63$ & $2 \cdot 7 \pm 0 \cdot 16$ \\
\hline
\end{tabular}

The net flux of acetate through the caccocolonic loops is expressed in $\mu \mathrm{mol} / \mathrm{g}$ wet or dry wt/20 $\mathrm{min}$. Each value represents the mean $\pm S E$ of 12 samples. There was no statistically significant difference between the net flux of acetate in the different loops. 


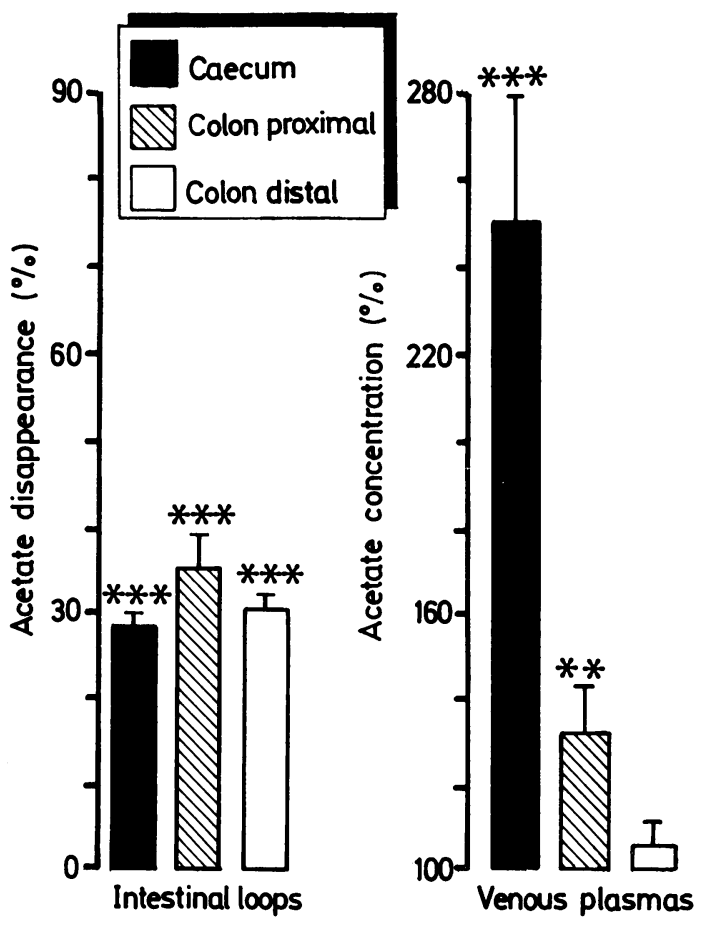

Fig. 2 Acetate disappearance from 12 caecocolonic loops is expressed as a \% of the initial acetate concentration in the test solution. Acetate concentration in venous plasma is expressed as $a \%$ of the acetate concentration in the arterial plasma. Each column with its bar represent mean $\pm S E$;

** significantly different at $p<0 \cdot 01 ;{ }^{* * *}$ significantly different at $p<0.001$ from controls.

\section{${ }^{14} \mathrm{C}$ incorporation into metabolites}

All tissues were able to convert acetate. On the autoradiographs radiocarbon was always detected in a number of metabolites: free amino acids, organic acids and sugars (Table 3; Fig. 1). In gut walls practically all the ${ }^{14} \mathrm{C}$ was recovered in free amino acids: alanine; aspartate, asparagine, cysteine; glutamate, glutamine, leucine and valine; but the radioactivity was mainly accounted for by glutamate $(75-80 \%)$. Radiocarbon was also detected in organic acids, in this case most of the labelling concerns the TCA cycle acids $(75-85 \%)$; some label was recovered in glycerate and lactate. Radioactivity was regularly found in fructose, glucose, and phosphorylating sugars. The total ${ }^{14} \mathrm{C}$ incorporation increased in an aboral direction, the values were respectively seven and 13 times higher in the proximal and distal colon than in the caecum. The high values obtained in distal colon were not only due to an increased labelling of organic acids but also to that of free amino acids which were 14 times more labelled in the distal colon. Among the amino acids aspartate, glutamate and glutamine were respectively 50,14 , and nine times more labelled in the distal hindgut. Irrespective of the total ${ }^{14} \mathrm{C}$ content in the large intestine tissues the labelling balance of the free amino acids, organic acids and sugars was remarkably constant (Fig. 3).

Most of the labelled metabolites present in hindgut walls were detectable in venous plasma, this is not the case in arterial plasma where radiocarbon was only found in citrate, lactate and glucose.

For $1 \mathrm{~g}$ of wet tissue the ${ }^{14} \mathrm{C}$ content of the liver was identical to the ${ }^{14} \mathrm{C}$ content of the caecal wall, but the accumulation of glutamate was not as great: $60 \%$ instead of $75 \%$.

\section{Specific radioactivities (SR)}

The specific radioactivity for aspartate and glutamate were relatively large and similar in the three gut tissues (Table 4). The specific radioactivity for cysteine decreased in an aboral

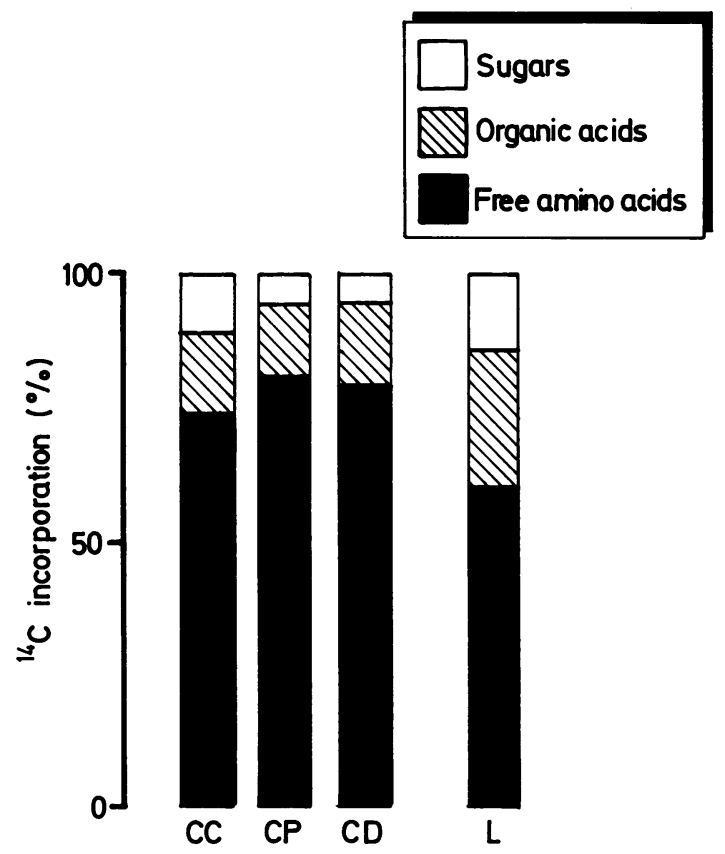

Fig. $3{ }^{14} \mathrm{C}$ incorporation into free amino acids, organic acids and sugars in caecal (CC), proximal and distal colon $(P C, D C)$ and liver $(L)$ tissues after introduction of $\left(1-{ }^{14} C\right)$ acetate into caecocolonic loops. Values are expressed as a $\%$ of the total ${ }^{14} \mathrm{C}$ incorporation. 
Table 3 Incorporation of ${ }^{14} \mathrm{C}$ into free amino acids, organic acids and sugars in gut and liver tissues and plasmas 20 minutes after introduction of $\left(1-{ }^{14} \mathrm{C}\right)$ acetate into caecocolonic loops

\begin{tabular}{|c|c|c|c|c|c|c|c|}
\hline & & \multicolumn{4}{|l|}{ Tissues } & \multicolumn{2}{|l|}{ Plasmas } \\
\hline & & Caecum & Proximal colon & Distal colon & Liver & Venous & Arterial \\
\hline \multicolumn{8}{|c|}{ Free amino acids } \\
\hline & Alanine & $0 \cdot 3 \pm 0 \cdot 14$ & $1 \cdot 0 \pm 0 \cdot 16$ & $1 \cdot 1 \pm 0 \cdot 31$ & $0 \cdot 7 \pm 0 \cdot 01$ & $0 \cdot 3 \pm 0 \cdot 13$ & - \\
\hline & Aspartate & $0 \cdot 3 \pm 0 \cdot 07$ & $8 \cdot 8 \pm 3 \cdot 21$ & $14 \cdot 7 \pm 3 \cdot 08$ & $0 \cdot 9 \pm 0 \cdot 15$ & $0 \cdot 2 \pm 0 \cdot 13$ & - \\
\hline & Asparagine & $0.4 \pm 0 \cdot 09$ & $1 \cdot 1 \pm 0 \cdot 29$ & $1 \cdot 9 \pm 0 \cdot 27$ & $0 \cdot 3 \pm 0 \cdot 04$ & - & - \\
\hline & Cysteine & $0 \cdot 3 \pm 0 \cdot 03$ & $0 \cdot 6 \pm 0 \cdot 24$ & $1 \cdot 6 \pm 0 \cdot 42$ & $0 \cdot 1 \pm 0 \cdot 09$ & $0 \cdot 2 \pm 0 \cdot 11$ & - \\
\hline & Glutamate & $5 \cdot 5 \pm 1 \cdot 58$ & $48 \cdot 3 \pm 11 \cdot 18$ & $78 \cdot 8 \pm 15 \cdot 67$ & $4 \cdot 2 \pm 0 \cdot 35$ & $0 \cdot 6 \pm 0 \cdot 19$ & - \\
\hline & Glutamine & $0 \cdot 6 \pm 0 \cdot 07$ & $0 \cdot 5 \pm 0 \cdot 11$ & $5 \cdot 1 \pm 0 \cdot 32$ & $0 \cdot 4 \pm 0 \cdot 18$ & - & - \\
\hline & Leucine & - & - & $0 \cdot 3 \pm 0 \cdot 24$ & $0 \cdot 1 \pm 0 \cdot 09$ & - & 一 \\
\hline & Valine & - & $1 \cdot 1 \pm 0 \cdot 38$ & $1 \cdot 5 \pm 0.48$ & $0 \cdot 2 \pm 0 \cdot 15$ & - & - \\
\hline & Total & $7 \cdot 4 \pm 0 \cdot 21$ & $61 \cdot 4 \pm 12 \cdot 53$ & $105 \cdot 0 \pm 18 \cdot 57$ & $6 \cdot 9 \pm 0 \cdot 41$ & $1 \cdot 3 \pm 0 \cdot 99$ & - \\
\hline \multicolumn{8}{|c|}{ Organic acids } \\
\hline & Citrate & $0 \cdot 2 \pm 0 \cdot 09$ & $4 \cdot 6 \pm 1 \cdot 80$ & $7 \cdot 3 \pm 2 \cdot 32$ & $0 \cdot 5 \pm 0 \cdot 09$ & $1 \cdot 4 \pm 0 \cdot 28$ & $0 \cdot 3 \pm 0 \cdot 09$ \\
\hline TCA & Fumarate & $0 \cdot 1 \pm 0 \cdot(19$ & $0 \cdot 7 \pm 0 \cdot 28$ & $1 \cdot 6 \pm 0 \cdot 42$ & $0 \cdot 3 \pm 0 \cdot 04$ & - & 一 \\
\hline cycle & Malate & $0 \cdot 4 \pm 0 \cdot 18$ & $1.7 \pm 0.47$ & $6 \cdot 5 \pm 3 \cdot 06$ & $0.7 \pm 0 \cdot 12$ & $0 \cdot 2 \pm 0 \cdot 08$ & - \\
\hline & Succinate & $0 \cdot 5 \pm 0 \cdot 09$ & $1 \cdot 7 \pm 0.43$ & $4 \cdot 1 \pm 1 \cdot 73$ & $0 \cdot 6 \pm 0 \cdot 02$ & $0 \cdot 4 \pm 0 \cdot 24$ & - \\
\hline & Glycerate & $0 \cdot 1 \pm 0 \cdot 01$ & $0 \cdot 3 \pm 0 \cdot 10$ & $1 \cdot 4 \pm 0 \cdot 56$ & $0 \cdot 2 \pm 0 \cdot 15$ & - & - \\
\hline & Glycolate & $0 \cdot 1 \pm 0 \cdot 09$ & $0 \cdot 1 \pm 0 \cdot 04$ & $0 \cdot 1 \pm 0 \cdot 08$ & - & - & - \\
\hline & Lactate & $0 \cdot 3 \pm 0 \cdot 09$ & $1 \cdot 0 \pm 0 \cdot 22$ & $2 \cdot 3 \pm 1 \cdot 04$ & $0 \cdot 7 \pm 0 \cdot 35$ & $0 \cdot 3 \pm 0 \cdot(19$ & $0 \cdot 3 \pm 0 \cdot 07$ \\
\hline & Total & $1 \cdot 7 \pm 0 \cdot 26$ & $10 \cdot 1 \pm 3 \cdot 20$ & $23 \cdot 3 \pm 8 \cdot 97$ & $3 \cdot 0 \pm 0 \cdot 54$ & $2 \cdot 3 \pm 0 \cdot 73$ & $0 \cdot 6 \pm 0 \cdot 16$ \\
\hline \multicolumn{8}{|c|}{ Sugars } \\
\hline & Fructose & $0 \cdot 4 \pm 0 \cdot() 3$ & $0.5 \pm 0.22$ & $2 \cdot 0 \pm 0 \cdot 86$ & - & - & - \\
\hline & Glucose & $0 \cdot 3 \pm 0 \cdot 08$ & $1 \cdot 0 \pm 0 \cdot 25$ & $0.7 \pm 0 \cdot 27$ & $1 \cdot 2 \pm 0 \cdot 15$ & $1 \cdot 5 \pm 0 \cdot 12$ & $0.7 \pm 0.07$ \\
\hline & P. oses & $0 \cdot 3 \pm 0 \cdot 06$ & $1 \cdot 4 \pm 0 \cdot 41$ & $1 \cdot 2 \pm 0 \cdot 36$ & $0 \cdot 1 \pm 0 \cdot 10$ & $0 \cdot 1 \pm 0 \cdot 05$ & - \\
\hline & Sucrose & - & $0 \cdot 4 \pm 0 \cdot 21$ & $0 \cdot 3 \pm 0 \cdot 13$ & - & - & - \\
\hline & Total & $1 \cdot 0 \pm 0 \cdot 27$ & $3 \cdot 3 \pm 0 \cdot 76$ & $4 \cdot 2 \pm 1 \cdot 27$ & $1 \cdot 3 \pm 0 \cdot 17$ & $1 \cdot 6 \pm 0 \cdot 18$ & $0 \cdot 7 \pm 0 \cdot 07$ \\
\hline Total & ${ }^{14} \mathrm{C}$ incorporation & $10 \cdot 0 \pm 0 \cdot 10$ & $74 \cdot 8 \pm 15 \cdot 24$ & $132 \cdot 5 \pm 11 \cdot 15$ & $11 \cdot 2 \pm 0 \cdot 88$ & $5 \cdot 2 \pm 0 \cdot 47$ & $1 \cdot 3 \pm 0 \cdot 87$ \\
\hline
\end{tabular}

${ }^{14} \mathrm{C}$ incorporation is expressed in $10^{3} \mathrm{dpm} / \mathrm{g}$ wet $\mathrm{wt} / 20 \mathrm{~min}$ or $10^{3} \mathrm{dpm} / \mathrm{ml} / 20 \mathrm{~min}$. Each value represents the mean $\pm \mathrm{SE}$ of six samples of tissue; the venous plasma is mean of the three plasma (caecal and colonic) withdrawn during the six experiments; ( - ) represents nil results. Differences in the variations of the ${ }^{14} \mathrm{C}$ incorporation into the three groups of metabolites were not statistically significant between proximal and distal colon; in contrast they were significant at $p<0 \cdot 01$ between caecal and proximal colon; at $p<0 \cdot 001$ between caecal and distal colon and between arterial and venous plasma.

direction, in contrast the specific radioactivity for alanine was low and constant. The specific radioactivity of organic acids is often missing (Table 4), this is because if labelling does occur, organic acid concentrations are often so low that they could not be quantitatively estimated.

\section{Discussion}

This study shows that the rabbit is able to absorb substantial amounts of acetate. Indeed we found an absorption rate of about $8 \mu \mathrm{mol} / \mathrm{cm}^{2} / \mathrm{h}$ which is greater than that observed in the rumen epithelium $^{24}$ and the large intestine of man, ${ }^{25} 26$ $\mathrm{pig}^{27}$ and pony. ${ }^{28}$ As the rate of disappearance in caecocolonic loops is comparable when a solution of identical concentration is introduced into the loops, it appears that the absorptive capacity in the hindgut does not diminish in an aboral direction. In vitro studies of acetate and transport across the hindgut epithelium of pony ${ }^{28}$ and pig $^{27}$ showed that acetate is absorbed at an approximately equivalent rate in caecal and colonic tissues. Its release onto the serosal side diminished in an aboral direction for the pig, however, but not for the pony. The authors concluded that, for the pig, a large portion of acetate was metabolised by the epithelium itself.

In the rabbit the high concentration of acetate normally present in the large intestine contents, ${ }^{69} 29$ its rapid absorption; $;{ }^{2}{ }^{30}$ its strikingly low concentration in colonic plasma and the labelling of the TCA cycle acids suggest that acetate is well utilised by the gut wall. The pattern of the distribution of ${ }^{14} \mathrm{C}$ into free amino acids, organic acids and sugars shows that irrespective of the tissue acetate follows the same pathway. In addition, the specific radioactivities show that acetate is mainly converted into aspartate and glutamate. The intense labelling of these two amino acids in the large intestine tissue raises some speculation as to the metabolism of acetate. We never found such an accumulation in earlier works 
Table 4 Specific radioactivity (SR) of free amino acids and organic acids in gut and liver tissues and plasmas 20 minutes after introduction of $\left(1-{ }^{14} \mathrm{C}\right)$ acetate into caecocolonic loops

\begin{tabular}{|c|c|c|c|c|c|c|c|}
\hline & & \multicolumn{4}{|l|}{ Tissues } & \multicolumn{2}{|l|}{ Plasmas } \\
\hline & & Caecum & Proximal colon & Distal colon & Liver & Venous & Arterial \\
\hline \multicolumn{8}{|c|}{ Free amino acids } \\
\hline & Alanine & $0 \cdot 3 \pm 0 \cdot 12$ & $0 \cdot 6 \pm() \cdot 28$ & $0 \cdot 2 \pm 0 \cdot() 6$ & $1 \cdot 3 \pm 0 \cdot 25$ & $2 \cdot 3 \pm 0 \cdot 89$ & (1) \\
\hline & Aspartate+asparagine & $19 \cdot 5 \pm 4 \cdot 81$ & $20 \cdot 1 \pm 1 \cdot 08$ & $17 \cdot 4 \pm 3 \cdot 35$ & $13 \cdot 6 \pm 1 \cdot 64$ & $12 \cdot 0 \pm 1 \cdot 06$ & (1) \\
\hline & Cysteine & $6 \cdot 6 \pm 0 \cdot 90$ & $2 \cdot 4 \pm() \cdot 86$ & $3 \cdot 2 \pm 0 \cdot 88$ & $0.5 \pm 0 \cdot 45$ & $17 \cdot 7 \pm 3 \cdot 58$ & (1) \\
\hline & Glutamate + glutamine & $6 \cdot 4 \pm 0 \cdot 23$ & $7 \cdot 1 \pm 0 \cdot 39$ & $5 \cdot 5 \pm(0 \cdot 71$ & $3 \cdot 5 \pm 0 \cdot 25$ & $11 \cdot 4 \pm 5 \cdot 14$ & (1) \\
\hline & Leucine & (1) & (1) & $(0 \cdot 4 \pm(0 \cdot 29$ & $0 \cdot 4 \pm 0 \cdot 38$ & (1) & (1) \\
\hline & Valine & (1) & $2 \cdot 5 \pm 0 \cdot 84$ & $1 \cdot() \pm 0 \cdot 35$ & $1 \cdot 4 \pm 1 \cdot 38$ & (1) & (1) \\
\hline \multicolumn{8}{|c|}{ Organic acids } \\
\hline & Citrate & $1 \cdot 0 \pm 0 \cdot 48$ & $0 \cdot 4 \pm 0 \cdot 16$ & $(2)$ & $(2)$ & $3 \cdot 2 \pm 0 \cdot 25$ & $3 \cdot 7 \pm 0 \cdot 82$ \\
\hline TCA & Fumarate & $1 \cdot 4 \pm 0 \cdot 67$ & $(2)$ & (2) & $0 \cdot 7 \pm(0 \cdot 04$ & $4 \cdot 4 \pm 2 \cdot 18$ & (1) \\
\hline \multirow[t]{5}{*}{ cycle } & Malate & $0 \cdot 5 \pm 0 \cdot 46$ & $(0 \cdot 2 \pm 0 \cdot 13$ & $(2)$ & $0 \cdot 9 \pm 0 \cdot(07$ & $1.7 \pm 0.95$ & (1) \\
\hline & Succinate & $4 \cdot 2 \pm 0 \cdot 65$ & $25 \cdot 3 \pm 6 \cdot 12$ & (2) & $1 \cdot 1 \pm 0 \cdot 08$ & $19 \cdot 0 \pm 10 \cdot 51$ & (1) \\
\hline & Glycerate & $0 \cdot 2 \pm 0 \cdot 06$ & (2) & (1) & $0 \cdot 1 \pm 0 \cdot 06$ & (1) & (1) \\
\hline & Glycolate & $0 \cdot 2 \pm 0 \cdot 15$ & (2) & (2) & $(2)$ & (1) & (1) \\
\hline & Lactatc & $0 \cdot 6 \pm 0 \cdot 18$ & $0 \cdot 2 \pm 0 \cdot 13$ & $(0) 6 \pm 0.32$ & $1 \cdot 3 \pm 0.56$ & $0 \cdot 5 \pm 0 \cdot(08$ & $1.9 \pm 0.76$ \\
\hline
\end{tabular}

Specific radioactivity is expressed in $\mu \mathrm{Ci} / \mu \mathrm{mol} / 100 \mathrm{~g}$ wet wt or in $\mu \mathrm{Ci} / \mu \mathrm{mol} / 10) \mathrm{ml}$ plasma. (1): metabolites isolated but not containing any significant counts; (2): quantitative estimations of these metabolites were not obtained. Each value represents the mean \pm SE of six samples of tissues; the venous plasma is the mean of the three plasmas (caccal and colonic) withdrawn during the six experiments. There was no statistically significant difference between the different specific radioactivity in the gut tissues except for the cysteine specific radioactivity $(\mathrm{p}<0.001)$. In the liver the specific radioactivity of alanine and glutamine was statistically different from those of the other tissues $(\mathrm{p}<0 \cdot 001)$.

with labelled butyrate ${ }^{8}$ or propionate (unpublished results). It is well known that the preferred respiratory fuels for the small intestine of rat and other species $^{31-33}$ are glutamine and glutamate. When glutamate is extensively oxidized more than half of its carbon skeleton may be converted into alanine. ${ }^{31}{ }^{32}$ In the hindgut of rat $^{34}$ and man $^{35}$ there is an aborally decreasing gradient of glutamate utilisation, linked with decreasing glutaminase (EC 3.5.1.2) and glutamate dehydrogenase (EC 2.3.2.1) activities in caecocolonic mucosa. The present finding is in line with that of preceding investigators. ${ }^{34}$ In effect a high glutamate concentration does not raise alanine production since the ratio Glu/Ala increases from the caecum to the rectum, while alanine variations are not significant. The rapid degradation of glutamate, however, must be initiated by the aminotransferases. ${ }^{36}$ Our results may explain the observations of Henning and $\mathrm{Hird}^{4}$ in the rabbit colon: In experiments with $\left(1-{ }^{14} \mathrm{C}\right)$ acetate applied to the epithelial surface of everted colonic sacs, they found that almost all the ${ }^{14} \mathrm{C}$ lost from the incubation fluids was taken up by the wall and that little carbon dioxide was released. In the present in vivo experiments, it appears that $\left(1-{ }^{14} \mathrm{C}\right)$ acetate was rapidly converted into other metabolites: aspartate and glutamate which are more slowly oxidised into carbon dioxide and hardly exported at all. Substantial labelling of glutamate was also reported by Mayfield et al ${ }^{37}$ in in vitro incubations of various sheep tissues with $\left(1-{ }^{14} \mathrm{C}\right)$ acetate.

The low levels of acetate in the colonic bloodstream imply that acetate catabolism by the gut wall is extremely efficient, particularly in the distal colon. The nature and the distribution of the radioactive carbon shows that acetate is used by the colonocytes as a source of energy but especially for protein ${ }^{38}$ and fat $^{39}$ synthesis. Thus it appears that the tissues of the rabbit large intestine use acetate as efficiently as those of the rumen. ${ }^{4(1-42}$

For the rabbit, the liver is an important site of acetate uptake, as it removes $43 \%$ of acetate reaching it $^{43}$ and practically all the labelled metabolites produced by the gut walls. The liver does not appear to accumulate glutamate to a great extent, it is possible that this amino acid is not stored, but rapidly utilised throughout the TCA cycle with production of alanine and glucose. ${ }^{4+46}$ The presence of an acetyl CoA synthetase (EC 6.2.1.1) mainly located in the cytosol fraction ${ }^{47}$ indicates that in the rabbit liver as in sheep ${ }^{48}$ and rat ${ }^{49}$ acetate is largely converted into fatty acids and carbon dioxide, because the enzymes involved in fatty acid synthesis are cytosolic. Leung and Bauman considered that in the rabbit the liver accounted for approximately two-thirds of the fatty acid synthesis.

In arterial plasma, acetate is the only VFA present in significant concentrations. 5716 There is 
no detectable labelling of free amino acids, meanwhile very slight radioactivity was found in citrate, lactate, and glucose, metabolites which, like acetate, are directly assimilable by extra-hepatic tissues. ${ }^{50-54}$

In conclusion, acetate is clearly an important nutrient for the colonic mucosa particularly for the distal colon, mediating a symbiotic existence between bacteria and the hindgut mucosa. In the light of our present and previous ${ }^{8}$ findings it would be reasonable to regard VFA in rabbit and certain other species not just as providers of energy to the whole organism, but as a predominant energy source for the colonic mucosa.

We thank J Carles and J Calmes for allowing us to use the facilities of their laboratory at the Institut Catholique of Toulouse, and also for their invaluable aid both in experiments and in discussion of results.

\section{References}

1 Hoover WH, Heitmann RN. Effects of dietary fiber levels on weight gain; cecal volume and volatile fatty acids production in rabbits. $J$ Nutr 1972 ; 102: 375-80.

2 Parker DS. The measurement of production rates of volatile fatty acids in the caecum of the conscious rabbit. BrJ Nutr 1976; 36: 61-78.

3 Henning SJ, Hird FJR. Ketogenesis from butyrate and acetate by the caecum and the colon of rabbits. Biochem J 1972; 130: 785-90.

4 Henning SJ, Hird FJR. Transport of acetate and butyrate in the hindgut of rabbits. Biochem J 1972; 130: 791-6.

5 Beauville M, Raynaud P, Vernay M. Concentration des acides gras volatils plasmatiques chez le lapin. Ann Rech Vét 1974; 5: 407-11.

6 Vernay M, Raynaud P. Répartition des acides gras volatils dans le tube digestif du lapin domestique. Ann Rech Vét 1975; 6: 357-77.

7 Bonnafous R. Raynaud P. Étude sur la concentration des AGV du matériel et des AGV et corps cétoniques plasmatiques au niveau des veines du gros intestin chez le lapin domestique. $2^{e}$ Journée de la Recherche Cunicole 1978; Toulouse, ASFC, ed, Communication no 5.

8 Vernay M, Marty J. Absorption and metabolism of butyric acid in rabbit hindgut. Comp Biochem Physiol 1984; 77: 89-96.

9 Frizzell RA, Koch MJ, Schultz SG. Ion transport by rabbit colon. I-Active and passive components. $J$ Membr Biol 1976; 27: 297-16.

10 Yorio T, Bentley PJ. Permeability of the rabbit colon in vitro. Am J Physiol 1977; 1: F5-F9.

11 Leng E. Absorption of inorganic ions and volatile fatty acids in the rabbit caecum. Br J Nutr 1978; 40: 509-19.

12 McCabe R, Cooke HJ, Sullivan LP. Potassium transport by rabbit descending colon. Am J Physiol 1982; 242: C81-C6.

13 Bonnafous R, Raynaud P. Mise en évidence d'une activité lysante du côlon proximal sur les microorganismes du tube digestif du lapin. Arch Sci Physiol 1968; 22: 57-64.

14 Bonnafous R, Raynaud P. Étude électrophorétique sur gel de polyacrylamide du suc colique de lapin Recherche d'un facteur lysant. CR Acad Sci [D] Paris 1969; 269: 1004-6.

15 Bonnafous R. Quelques aspects de la physiologie colique en relation avec la dualité de l'excrétion fécale chez le lapin. Université P. Sabatier: Thèse d'état, 1973.

16 McMillan RT, Edwards NA, Parker DS. Observations on the volatile fatty acids present in the hindgut and in the blood of the domestic rabbit. Proc Nutr Soc 1975; 34: $21 \mathrm{~A}-22 \mathrm{~A}$

17 Leng E, Hörnicke H. Tagesrhythmische Unterschiede in der Zusammensetzung des Blindderminhaltes von Kaninchen. Z Versuchstierkd 1975; 17: 285-99.

18 Schurmann P. Separation of phosphate esters and algal extracts by thin-layer electrophoresis and chromatography. J Chromatogr 1969; 39: 507-9.

19 Lavergne D, Bismuth E, Champigny ML. Physiological studies on two cultivars of Pennisetum: $P$ americanum 23 DB a cultivated species and $P$ mollissimum a wild species. Photosynthetic carbon metabolism. Z Pflanzenphysiol 1979; 91: 291 303 .

20 Carles J, Abravanel G. Dosage automatique et simultané des acides aminés et des guanidines. Bull Soc Chim 1970; 52: 453-4.

21 Carles J. Le dosage automatique des acides organiques par potentiométrie. Bull Soc Chim 1968; 50: $1341-5$.

22 Rémésy $C$, Demigné $C$. Determination of volatile fatty acids in plasma after ethanolic extraction. Biochem J 1974; 141: 85-91.

23 Hyden S. A turbidometric method for the determination of higher polythylene glycol in biological materials. Lantbrukshögsk Ann 1955; 22: 139-45.

24 Stevens CE, Stettler BK. Factors affecting the transport of volatile fatty acids across rumen epithelium. Am J Physiol 1966; 210: 365-72.

25 McNeil NI. Cummings JH. James WPT. Short chain fatty acid absorption by the human large intestine. Gut 1978; 19: 819-22.

26 McNeil NI, Cummings JH. Evidence for regional variations in large intestinal function. [Abstract] Gut 1979; 20: A439.

27 Argenzio RA. Southworth M. Sites of organic acid production and absorption in the gastrointestinal tract of the pig. Am J Physiol 1974; 228: 454-60.

28 Argenzio RA. Southworth M. Stevens CE. Sites of organic acid production and absorption in the equine gastrointestinal tract. Am J Physiol 1974; 226: 1043-50.

29 Henning SJ, Hird FJR. Diurnal variations in the concentrations of volatile fatty acids in the alimentary tract of wild rabbits. Br J Nutr 1972; 27: 57-64. 
30 Woodnutt G, Parker DS. Absorption of acetate and butyrate from the caecum of the rabbit. [Abstract] Proc Nutr Soc 1981; 40: 17A.

31 Watford M, Lund P, Krebs HA. Isolation and metabolic characteristics of rat and chicken enterocytes. Biochem J 1979; 178: 589-96.

32 Windmueller HG, Spaeth AE. Uptake and metabolism of plasma glutamine by the small intestine. J Biol Chem 1974; 249: 5070-9.

33 Windmueller $\mathrm{HG}$, Spaeth AE. Identification of ketone bodies and glutamine as the major respiratory fuels in vivo for post-absorptive rat small intestine. $J$ Biol Chem 1978; 253: 69-76.

34 Pinkus LW, Windmueller HG. Phosphate-depend glutaminase of small intestine: localization and role in intestinal glutaminase metabolism. Arch Biochem Biophys 1977; 182: 506-17.

35 Roediger WEW. Role of anaerobic bacteria in the metabolic welfare of the colonic mucosa in man. Gut 1980; 21: 793-8.

36 Krebs HA, Lowenstein JM. The tricarboxylic acid cycle. In: Greenberg DM, ed. Metabolic pathways. New York: Academic Press, 1960; 1: 129.

37 Mayfield ED, Bensadoun A, Johnson BC. Acetate metabolism in ruminant tissues. $J$ Nutr 1966; 89: 189-96.

38 Rémésy C. Contribution à l'étude de la production et du métabolisme des acides gras volatils chez le rat. Université de Clermont-Ferrand: Thèse de spécialité, 1973.

39 Leung TT, Bauman DE. In vivo studies of the site of fatty acid synthesis in the rabbit. Int J Biochem 1975; 6: $801-5$.

40 Spahr SL, Kesler EM, Flipse RJ. Utilization of blood acetate and butyrate by the isolated perfused goat rumen. J Dairy Sci 1965; 48: 228-33.

41 Bergman EN, Wolff JE. Metabolism of volatile fatty acids by liver and portal-drained viscera in sheep. Am J Physiol 1971; 221: 586-92.

42 Pethick DW, Lindsay DB, Barker PJ, Northrop AJ.
Acetate supply and utilization by the tissues of sheep in vivo. BrJ Nutr 1981; 46: 97-110.

43 Vernay MY. Recherches sur la production, l'absorption et l'utilisation des acides gras volatils dans le tube digestif du lapin. Université de Toulouse: Thèse de spécialité, 1974.

44 Hanson PJ, Parsons DS. Metabolism and transport of glutamine and glucose in vascularly perfused rat small intestine. Biochem J 1977; 166: 509-19.

45 Aikawa T, Matsutaka H, Takezawa K, Ishikawa E. Gluconeogenesis and amino acids metabolism. I. Comparison of various precursors for hepatic gluconeogenesis in vivo. Biochim Biophys Acta 1972; 279: $234-44$.

46 Felig P. The glucose-alanine cycle. Metabolism 1973; 22: 179-207.

47 Woodnutt G, Parker DS. Rabbit liver acetylCoA synthetase. Biochem J 1978; 175: 757-9.

48 Snoswell AM, Koundakjian PP. Relationship between carnitine and coenzyme A ester in tissues of normal and alloxan-diabetic sheep. Biochem J 1972; 127: 133-41.

49 Hanson RW, Ballard FJ. The relative significance of acetate and glucose as precursors for lipid synthesis in liver and adipose tissue from ruminants. Biochem $J$ 1967; 105: 529-36.

50 Drury DR, Wick AN. Metabolism of lactic acid in the intact rabbit. Am J Physiol 1956; 184: 304-8.

51 Smith S. Lipogenesis in rabbit adipose tissue. J Lipid Res 1975; 16: 324-31.

52 Jones CS, Parker DS. Arteriovenous differences studies on lactating rabbit mammary gland. Proc Nutr Soc 1977; 26: 2A.

53 Vézinhet A, Nouguès J. Postnatal evolution of lipogenesis in adipose tissue and liver of lamb and rabbit. Ann Biol Anim Biochim Biophys 1977; 17: 851-63.

54 Jones CS. Parker DS. The metabolism of glucose, acetate and palmitate in the lactating rabbit. Comp Biochem Physiol 1981; 69B: 837-42. 